\title{
PERTANGGUNGJAWABAN PIDANA SEORANG IBU MENJUAL ANAK DALAM KANDUNGAN (TINJAUAN UNDANG-UNDANG NOMOR 23 TAHUN 2002)
}

\author{
Made Warka \\ Ario Rizky Renandha F. Kadir \\ Fakultas Hukum Universitas 17 Agustus 1945 Surabaya \\ e-mail:warka_dpk@ymail.com
}

\begin{abstract}
ABSTRAK
Di era globalisasi, perkembangan kejahatan semakin terus meningkat. Perdagangan orang merupakan bentuk perbudakan secara modern, bahkan seorang ibu sebagai orangtua tega menjual anak dalam kandungan karena kebutuhan materi. Atas peristiwa tersebut, penulis tertarik untuk meneliti, dengan tujuan untuk mengetahui bagaimanakah bentuk pertanggungjawaban pidana seorang ibu yang menjual anak dalam kandungan. Penelitian ini menggunakan metode yuridis normatif, dengan pendekatan statute approach dan conseptual approach. Kemudian sumber bahan hukum yang diperoleh dari undang-undang, buku-buku hukum, internet, dan pendapat para pakar hukum. Proses berpikir deduktif, dan dianalisis secara kualitatif, yaitu kaedah dan teknik untuk keingintahuan penulis pada suatu gejala yuridis atau cara untuk menemukan kebenaran dalam pengetahuan. Hasil penelitian dimana seorang ibu yang menjual anak dalam kandungan, akibat perbuatan yang telah lalai dan pelanggaran melanggar ibu dimintai pertanggungjawaban dengan pidana penjara dan denda sesuai dengan Undang-Undang Perlindungan Anak.

Kata kunci: perdagangan orang, perlindungan anak, pertanggungjawaban pidana.
\end{abstract}

\begin{abstract}
In the era of globalization, the development of crime keeps on increasing. Trafficking in persons is a modern form of slavery, even a mother as a parent have the heart to sell her unborn child because of material needs. Of the event, the authors are interested in researching, in order to determine how the form of criminal liability of a mother who sells her unborn child. This study uses a normative juridical method, by using statute approach and conseptual approach. Then the material source of law derived from the law, law books, the internet, and the opinions of legal experts. The process of reasoning is deductive one, and it is analyzed qualitatively, that is the utility and techniques for author's curiosity on a juridical symptoms or how to find the truth in knowledge. Results of studies in which a mother who sells her unborn child, due to negligent acts and violations will has to be accountable, and will put into the prison and receive a fine in accordance with the Child Protection Act.
\end{abstract}

Keywords: human trafficking, child protection, criminal liability.

\section{PENDAHULUAN}

Dalam sejarah bangsa Indonesia, perdagangan orang pernah ada yaitu melalui perbudakan atau melalui penghambaan. Pada masa kerajaan-kerajaan di Jawa, perdagangan orang, yaitu perempuan pada saat itu merupakan bagian pelengkap dari sistem pemerintah feodal. Pada masa itu konsep kekuasaan raja digambarkan sebagai kekuasaan yang sifatnya agung dan mulia. Kekuasaan raja tidak terbatas, hal ini tercermin dari banyaknya selir yang dimilikinya. Beberapa orang dari selir-selir tersebut adalah putri bangsawan yang diserahkan kepada raja sebagai tanda kesetiaan. Sebagian lain adalah persembahan dari kerajaan lain dan ada juga selir yang berasal dari lingkungan masyarakat bawah yang dijual atau diserahkan oleh keluarganya dengan maksud agar keluarga tersebut mempunyai keterkaitan dengan keluarga istana, sehingga akan dapat meningkatkan statusnya. Perempuan yang dijadikan selir berasal dari daerah tertentu. Sampai sekarang daerah-daerah tersebut merupakan legenda.

Koentjoro mengidentifikasi ada 11 Kabupaten di Jawa yang dalam sejarah terkenal sebagai pemasok 
perempuan-perempuan untuk kerajaan dan ternyata sampai sekarang ini daerah tersebut masih terkenal sebagai pemasok perempuan untuk diperdagangkan, daerah itu adalah Jawa Barat (Indramayu, Karawang, Kuningan), Jawa Tengah (Pati, Jepara, Wonogiri), Jawa Timur (Blitar, Malang, Banyuwangi, Lamongan) (Farhana, 2010:1)

Di Bali juga terjadi hal tersebut, misalnya seorang janda dari kasta rendah tanpa dukungan yang kuat dari anggota keluarganya, secara otomatis menjadi milik raja. Jika raja memutuskan tidak mengambil dan tidak masuk ke lingkungan istana, maka dia akan dikirim ke luar kota untuk menjadi pelacur dan sebagian penghasilannya harus diserahkan kepada raja secara teratur. Perlakuan terhadap orang, yaitu perempuan sebagai barang dagangan tidak terbatas di Jawa saja, tetapi kenyataannya di seluruh Asia (Farhana, 2010:2)

Di era globalisasi, perbudakan marak kembali dalam wujudnya yang ilegal dan berupa perdagangan orang melalui bujukan, ancaman, penipuan, rayuan untuk direkrut dan dibawa ke daerah lain bahkan ke luar negeri untuk diperjualbelikan dan dipekerjakan di luar kemauannya sebagai pekerja seks, pekerja paksa dan/atau bentuk-bentuk eksploitasi lainnya.

Perdagangan orang yang mayoritas perempuan dan anak-anak, merupakan jenis perbudakan pada era modern ini dan dampak krisis multidimensional yang dialami Indonesia. Kenyataan bahwa yang lebih dominan korban adalah perempuan dan anak karena merekalah kelompok yang sering menjadi sasaran dan dianggap paling rentan. Korban perdagangan orang biasanya ditipu, diberlakukan tidak manusiawi, dan dieksploitasi. Bentuk-bentuk eksploitasi itu sendiri diantaranya dengan cara memperlakukan korban untuk bekerja yang mengarah pada praktik-praktik eksploitasi seksual, perbudakan atau bentuk-bentuk perbudakan modern, perbuatan transplantasi organ tubuh untuk tujuan komersial, sampai penjualan bayi yang dimaksudkan untuk tujuan dan kepentingan mendapatkan keuntungan besar bagi para pelaku perdagangan orang.

Perdagangan orang merupakan bentuk perbudakan secara modern, terjadi baik dalam tingkat nasional dan internasional. Dengan berkembangnya teknologi informasi, komunikasi, dan transformasi, maka modus kejahatan perdagangan manusia semakin canggih. Perdagangan orang bukan kejahatan biasa. terorganisir dan lintas negara, sehingga dapat dikategorikan sebagai transnational organized cryme. Canggihnya cara perdagangan orang tersebut harus diikuti dengan perangkat hukum yang dapat menjerat pelaku.
Perdagangan orang sangat bertentangan dengan hak asasi manusia karena perdagangan orang melalui cara ancaman, pemaksaan, penculikan, penipuan, kecurangan, dan kebohongan serta penyalahgunaan kekuasaan, bertujuan prostitusi, pornografi, kekerasan atau eksploitasi, kerja paksa, perbudakan atau praktikpraktik serupa. Jika salah satu cara tersebut di atas terpenuhi, maka terjadi perdagangan orang yang termasuk sebagai kejahatan yang melanggar hak asasi manusia. Pengertian dari hak asasi manusia adalah seperangkat hak yang melekat pada hakikat dan keberadaan manusia itu sebagai mahluk Tuhan Yang Maha Esa dan merupakan anugerahNya yang wajib dihormati, dijunjung tinggi dan dilindungi oleh negara, hukum, pemerintah, dan setiap orang demi kehormatan serta perlindungan harkat dan martabat manusia.

Berdasarkan definisi Hak Asasi Manusia dari Pasal 1 angka 1 Undang-Undang Nomor 39 Tahun 1999 tentang Hak Asasi Manusia (yang selanjutnya disebut UU HAM), maka dapat dijelaskan bahwa hak asasi manusia merupakan hak-hak dasar atau hakhak pokok yang dibawa manusia sejak lahir atau pun masih dalam kandungan sebagai anugerah Tuhan Yang Maha Esa. Hak-hak asasi ini menjadi dasar daripada hak-hak dan kewajiban-kewajiban yang lain. Hak yang melekat pada manusia, yaitu hak hidup dengan selamat, hak kebebasan, dan hak kesamaan yang sifatnya tidak boleh dilanggar oleh siapa pun juga. Hak asasi manusia dihubungkan dengan kodrat, harkat, dan martabat manusia, maka hak asasi manusia bersumber pada kodratnya sebagai makhluk Allah. Manusia diciptakan Allah untuk hidup, maka hidup adalah hak asasi manusia dan hak asasi manusia tersebut bersumber pada harkat dan martabatnya, karena diciptakan oleh Allah dengan kemampuan berpikirnya, bernalar, mengeluarkan pendapat dan pikiran. Manusia dibekali karsa untuk mengadakan pilihan secara bebas menurut keinginannya sendiri berdasarkan rasa tanggung jawab. Apabila persamaan derajat, hak dan kewajiban mengacu kepada hidup untuk bermasyarakat, berbangsa, dan bernegara, maka setiap warga masyarakat juga akan diperlakukan sama kedudukan hak dan kewajibannya dihadapan moral bangsa, serta norma-norma sopan santun yang berlaku di dalam masyarakat. Menjadi kewajiban dari pemerintah atau negara hukum untuk mengatur pembatasan-pembatasan demi kepentingan umum dan kepentingan bangsa dan negara.

Perdagangan orang telah dikriminalisasi dalam hukum Indonesia. Perdagangan orang disebutkan secara eksplisit dalam Pasal 297 Kitab Undang- 
Undang Hukum Pidana (yang selanjutnya disebut KUHP) menyatakan bahwa perdagangan wanita dan perdagangan anak-anak laki-laki yang belum cukup umur, diancam dengan pidana penjara paling lama enam tahun.

Perdagangan orang adalah tindakan perekrutan, pengangkutan, dan penampungan, serta pengiriman, pemindahan, atau penerimaan seseorang dengan suatu ancaman kekerasan, penggunaan kekerasan, ataupun penculikan, dan penyekapan, pemalsuan, penipuan, penyalahgunaan kekuasaan atau posisi rentan, penjeratan utang atau memberi bayaran atau manfaat, sehingga memperoleh persetujuan dari orang yang memegang kendali atas orang lain tersebut, baik yang dilakukan di dalam negara maupun antarnegara, untuk tujuan eksploitasi atau mengakibatkan orang tereksploitasi.

Walaupun perdagangan orang telah dinyatakan secara eksplisit telah dikriminalisasi, tetapi tidak ada definisi resmi tentang perdagangan orang dalam Pasal 297 KUHP, selain itu sanksi pidana yang diberikan terlalu ringan dan tidak sepadan dengan dampak yang diderita korban akibat kejahatan perdagangan orang. Kemudian UU HAM juga mengatur tentang perdagangan orang pada Pasal 65 UU HAM yang menyatakan setiap anak berhak untuk memperoleh perlindungan dari kegiatan eksploitasi dan pelecehan seksual, penculikan, dan perdagangan anak, serta dari berbagai bentuk-bentuk penyalahgunaan narkotik, psikotropika, dan zat adiktif lainnya. Dalam Pasal 65 UU HAM di atas tidak ada sanksi yang tercantum bagi pelanggar pasal ini dan/atau kaki tangannya. Sehingga di dalam praktiknya kedua pasal di atas yaitu Pasal 297 KUHP dan Pasal 65 UU HAM ini sulit untuk menyelesaikan kasus-kasus perdagangan orang yang ada. Selain itu kedua pasal tersebut tidak memberikan perlindungan terhadap saksi dan korban tindak pidana perdagangan orang.

Dengan terus menerus berkembangnya kejahatan perdagangan orang, perlunya peraturan khusus yang dapat menjerat pelaku dengan sanksi pidana yang sepadan serta memberikan perlindungan bagi saksi dan korban tindak pidana perdagangan orang, maka pemerintah menetapkan Undang-Undang Nomor 21 Tahun 2007 tentang Pemberantasan Tindak Pidana Perdagangan Orang (yang selanjutnya disebut UU PTPPO) yang disahkan pada tanggal 19 April 2007. Dalam undang-undang ini telah ada definisi resmi tentang perdagangan orang dan telah memberikan perlindungan bagi saksi dan korban. Adapun definisi dari perdagangan orang terdapat pada Pasal 1 angka 1 UU PTPPO.
Mengingat bahwa lebih dominan korban dari perdagangan orang adalah anak yang merupakan amanah dan karunia Tuhan Yang Maha Esa, yang di dalam dirinya juga melekat harkat dan martabat sebagai manusia yang seutuhnya. Serta anak adalah tunas, potensi, dan generasi muda penerus cita-cita perjuangan bangsa, memiliki peran strategis dan mempunyai ciri dan sifat khusus yang menjamin kelangsungan eksistensi bangsa dan negara pada masa depan. Agar setiap anak kelak mampu memikul tanggung jawab tersebut, maka ia perlu mendapat kesempatan yang seluas-luasnya untuk dapat tumbuh dan berkembang secara optimal, baik fisik, mental maupun sosial, dan berakhlak mulia, sehingga perlu dilakukan upaya perlindungan untuk mewujudkan kesejahteraan anak dengan memberikan jaminan terhadap pemenuhan hak-haknya serta dengan adanya perlakuan tanpa diskriminasi.

Dengan demikian pemerintah telah menetapkan peraturan khusus yaitu yang mengatur mengenai anak yaitu Undang-Undang Nomor 23 Tahun 2002 tentang Perlindungan Anak (yang selanjutnya disebut UU Perlindungan Anak). Perlindungan anak bertujuan untuk menjamin terpenuhinya hak-hak anak agar dapat hidup, tumbuh, berkembang, dan berpartisipasi secara optimal sesuai dengan harkat dan martabat kemanusiaan, mendapat perlindungan dari kekerasan dan diskriminasi, demi terwujudnya anak Indonesia yang berkualitas, berakhlak mulia, dan sejahtera, sesuai dalam Pasal 3 UU Perlindungan Anak.

Kejahatan terhadap anak semakin berkembang terlebih terhadap perdagangan anak, berikut laporan dari catatan akhir pada tahun 2011 Komisi Nasional Perlindungan Anak yaitu anak yang membutuhkan suatu perlindungan khusus dari ancaman perdagangan untuk tujuan ekploitasi seksual komersial yang turut meningkat, tahun 2011 Komisi Nasional Perlindungan Anak menerima pengaduan 480 anak korban ESKA, jumlah ini meningkat jika dibandingkan pada jumlah pengaduan tahun 2010 yakni 412 kasus. Peningkatan angka ini cukup memprihatinkan. Modusnya, selain tipu muslihat, janji-janji untuk dipekerjakan, tetapi berkembang modus baru yakni penculikan dengan pembiusan yang dilakukan bagi anak-anak remaja pada saat pergi dan pulang sekolah maupun melalui kecanggihan teknologi seperti internet dan situs-situs lainnya juga (http://komnaspa.wordpress.com/2011/ 12/21/catatan-akhir-tahun-2011-komisi- nasionalperlindungan-anak/, diunduh pada hari Selasa, 30 Oktober 2012, 16.00 WIB).

Kemudian ada salah satu kasus yang terjadi di Jakarta Utara, yaitu tepatnya di Kampungbeting, 
Tugu Utara, Koja. Berdalih terlilit utang, seorang ibu muda telah tega menjual bayi yang masih dalam kandungannya. Jabang bayi yang belum jelas jenis kelaminnya itu dihargai Rp.1.000.000,00 (satu juta rupiah) (http://megapolitan.kompas.com/read/2010/ 02/12/08391384/bayi.dalam.Kandungan.pun.Diju al.Rp.1,Juta, diunduh pada hari Sabtu, 27 Oktober 2012, 16.30 WIB). Ibu dengan nama samaran Santi dan suaminya dengan nama samaran Anto, mereka tinggal bersama di Kampungbeting yang baru tiga hari pindah dari Kampungsawah, Semper Timur, Cilincing. Santi telah menawarkan darah dagingnya yang masih dalam kandungan yang berusia delapan bulan itu kepada orang lain. Dia mengaku terlilit utang sebesar Rp.550.000,00 (lima ratus lima puluh ribu rupiah). Dia juga mengakui bahwa sudah ada dua orang pembeli yang akan membeli anaknya dengan harga Rp.1.000.000,00 (satu juta rupiah), namun dia tidak memberitahukan identitas calon pembeli tersebut karena takut terjadi apa-apa dikemudian hari kelak. Santi memberikan syarat kepada calon pembeli anaknya itu bahwa dia masih tetap bisa menengok anaknya bila suatu saat nanti dia merindukan anaknya tersebut, walaupun dia dianggap sebagai orang lain. Santi mengatakan bahwa perbuatan yang dia lakukan bertentangan dengan kata hatinya, namun karena akibat derita kemiskinan yang dia alami sehingga dia tega melakukan hal tersebut. Selain itu, menurut Santi suaminya tidak lagi bekerja sebagai juru mudi di kapal tug boat karena dipecat. Sehingga dia harus melunasi utangnya sebesar Rp.550.000,00 (lima ratus lima puluh ribu rupiah) kepada pemilik kontrakan rumah sebelumnya yang di kampung sawah. Pada pemilik kontrak rumah itu dia sudah berjanji untuk dapat melunasi dan apabila utangnya itu telah lunas, selain dia terbebas dari utang-utangnya dia juga dapat mengambil kembali Ijazah dan Buku Pelaut milik suaminya yang telah menjadi jaminan utang tersebut, sehingga dengan adanya Ijazah dan Buku Pelaut itu maka suaminya bisa dapat kembali bekerja. Selain itu menurut Santi, alasan dia menjual anaknya selain karena terdesak utang yang harus dilunasi dia juga tidak mampu untuk membayar persalinannya dan juga melengkapi tuntutan hidup yang begitu besar dan dia juga harus membayar uang sewa kontrakan rumah yang ditinggali bersama suami sebesar Rp. $250.000,00$ (dua ratus lima puluh ribu rupiah) per bulannya. Sementara itu, Sekretaris Jenderal Komisi Nasional Perlindungan Anak, Arist Merdeka Sirait, menjelaskan bahwa tindakan yang dilakukan oleh Santi merupakan tindakan yang menyalahi hukum. Itu tidak dibenarkan secara agama maupun hukum mesti itu baru sekedar niat. Apa yang dilakukan si ibu itu sudah tergolong penjualan anak. Hanya saja, modus yang dilakukan beralasan ekonomi. Namun yang jelas apa pun alasannya, itu tidak dibenarkan. Kalau si ibu tidak mampu membiayai anak tersebut serahkan anak itu kepada negara. Negara yang akan bertanggung jawab. Selain itu, Dinas Sosial harus menghambat niat itu dan memberikan jaminan dengan membantu si ibu. Kalaupun nanti si ibu khawatir akan ongkos persalinan, silakan saja ajukan surat keluarga miskin atau sejenisnya dan pemerintah tidak boleh menolak keinginan bagi mereka yang betul-betul tidak mampu. Arist menjelaskan selanjutnya bahwa kasus ini merupakan salah satu bentuk perdagangan orang. Sangat tidak masuk akal karena alasan untuk membayar kontrakan harus menjual anaknya.

Data yang diterima Komisi Nasional Perlindungan Anak dari hasil investigasi Lembaga Perlindungan Anak (LPA) di Kota Pontianak, di Malaysia tahun 2010 di perbatasan antara Brunei Darusalam dan Malaysia, yaitu telah ditemukan ratusan anak-anak remaja Indonesia yang terjebak menjadi korban dari eksploitasi seksual terselubung. Anak-anak remaja Indonesia yang direkrut oleh sindikat terorganisir perdagangan anak untuk dipekerjakan untuk melayani para penikmat seksual sampai saat ini belum juga bisa dapat diselamatkan, walaupun masalah ini juga sudah dilaporkan kepada pemerintah daerah (http: //komnaspa.wordpress.com/2011/12/21/catatanakhir-tahun-2011-komisi-nasional-perlindungananak/, diunduh pada hari Selasa, 30 Oktober 2012, 16.20 WIB).

\section{PERUMUSAN MASALAH}

Bagaimana bentuk pertanggungjawaban pidana seorang ibu menjual anak dalam kandungan tinjauan UU Perlindungan Anak.

\section{METODE PENELITIAN}

Penelitian ini yuridis normatif, tipe penelitian yuridis normatif adalah penelitian menggunakan bahan-bahan hukum yang ada untuk memecahkan persoalan yang ada berdasarkan UU Perlindungan Anak. Pendekatan masalahnya dengan menggunakan pendekatan masalah statute approach dan conseptual approach. Statute approach yaitu pendekatan yang dilakukan dengan mengidentifikasi serta membahas peraturan perundang-undangan yang berlaku, dalam hal ini adalah UU Perlindungan Anak. Sedangkan pendekatan secara conseptual approach yaitu suatu pendekatan melalui literatur dan bahan bacaan serta pendapat para sarjana. 


\section{PEMBAHASAN}

Penyelenggaraan perlindungan terhadap anak merupakan kewajiban dari berbagai pihak. Namun dalam hal ini pihak yang paling berperan adalah pihak orangtua, karena orangtualah yang mempunyai peran, kewajiban dan tanggung jawab yang sangat penting dalam sebuah keluarga atau rumah tangga. Awal pertumbuhan baik tidaknya akhlak anak tersebut dari didikan orangtua.

Berikut ini merupakan beberapa bentuk umum dari tanggung jawab orangtua terhadap anak yaitu Anak mempunyai hak untuk hidup; Menyusui; Memberi nama yang baik; Mendidik anak; Memberikan makan dan keperluan lainnya; Memberikan perawatan dan pendidikan kesehatan; Memberikan kepada anak tempat yang baik dalam hati orangtua; Memberi kasih sayang; Menikahkannya (http://uripsantoso.wordpr ess.com/2009/04/26/kewajiban-orang-tua-terhadapanak/, diunduh pada hari Kamis, 27 Desember 2012, 20.57 WIB)

Kemudian berdasarkan Pasal 26 ayat (1) UU Perlindungan Anak, yang disebut kewajiban dan tanggungjawab pihak orangtua terhadap anak yaitu orangtua berkewajiban dan bertanggungjawab untuk Mengasuh, memelihara, mendidik, dan melindungi anak; Menumbuhkembangkan anak sesuai dengan kemampuan, bakat, dan minatnya; dan Mencegah terjadinya perkawinan pada usia anak-anak.

Bentuk-bentuk kewajiban dan tanggung jawab orangtua yang telah dijelaskan di atas, bilamana orangtua telah melalaikan kewajiban dan tanggung jawabnya tersebut sehingga mengakibatkan tidak terlindunginya hak-hak anak, maka orangtua tersebut dapat dimintai pertanggungjawaban atas kelalaiannya. Adapun pengertian orangtua adalah ayah dan/atau ibu kandung, atau ayah dan/atau ibu tiri, atau ayah dan/atau ibu angkat, berdasarkan Pasal 1 angka 4 UU Perlindungan Anak.

Berkaitan dengan peristiwa di bagian pendahuluan, seorang ibu yang menjual anak dalam kandungan, maka seorang ibu tersebut telah melanggar kewajiban dan tanggung jawabnya sehingga dapat dimintai pertanggungjawaban. Namun bukan hanya ibu saja yang dimintai pertanggungjawaban, ayah atau suami dari ibu tersebut dapat dimintai pertanggungjawaban juga, karena sesuai dengan UU Perlindungan Anak Pasal 1 angka 4 bahwa orangtua adalah ayah dan/atau ibu kandung. Pada peristiwa tersebut orangtua telah melalaikan kewajiban dan tanggung jawabnya sebagai orangtua untuk mengasuh, memelihara, mendidik, dan melindungi anak mereka tersebut, mereka malah menjual anaknya yang masih dalam kandungan itu untuk kepentingan mereka saja tanpa memperhatikan dan mempedulikan hak-hak anaknya. Sehingga sudah sepantasnya atas perbuatan yang mereka lakukan mereka harus mempertanggungjawabkan.

Terdapat beberapa faktor internal penjualan anak antara lain: Pertama, Faktor Ekonomi. Pertumbuhan ekonomi sejak terjadinya krisis ekonomi tahun 1997 mengalami penurunan bahkan setelah terjadinya bom Bali. Biro Pusat Statistik Indonesia memperkirakan bahwa kurang lebih 38 juta orang Indonesia hidup di bawah garis kemiskinan dengan pendapatan kurang dari US\$1 (Satu Dollar) per hari (Rika Saraswati, 2009:84). Kemiskinan membuat keluarga khususnya orangtua tidak mampu untuk membiayai keluarga khususnya anak. Mulai dari biaya pendidikan dan keperluan untuk kehidupan sehari-hari. Dengan keadaan seperti ini anak harus ikut bekerja dengan alasan membantu orangtuanya sehingga anak-anak sering mengalami eksploitasi, misalnya menjadi pengamen, penyemir sepatu, pengemis, penjual koran dan sebagainya. Bahkan anak-anak tersebut diberikan target oleh orangtua dari hasil kerja mereka yang akan disetor pada orangtuanya. Kemiskinan ini juga membuat para orangtua mudah terbujuk rayu oleh pelaku-pelaku perdagangan anak dengan iming-iming serta janji palsu akan pekerjaan yang dapat membuat hidup lebih baik dengan gaji yang besar.

Kedua, Faktor Lemahnya Pencatatan Kelahiran. Tidak tercatat dan tidak terdokumentasinya anakanak dan orang dewasa, terutama mereka yang ada di pedesaan sangat rentan mengalami eksploitasi dan hal ini seperti memberi fasilitas kemudahan terjadinya perdagangan (Rika Saraswati, 2009:86). Para pelaku perdagangan anak memanfaatkan kesempatan ini karena bagi mereka sangat mudah untuk melakukan aksinya dengan membuat umur yang tidak sebenarnya sehingga para anak-anak tersebut dapat diizinkan ke luar negeri untuk diperdagangkan.

Ketiga, Faktor Terjerat Utang. Penjeratan utang yang terjadi terkadang dijadikan sebagai senjata untuk membuat orang menjadi penghambaan. Sehingga terkadang membuat orangtua yang memiliki utang untuk memberikan anaknya untuk bekerja, diperistri, atau lain hal untuk membayar utang-utang tersebut.

Keempat, Faktor Kehancuran Keluarga (Broken Home). Kehancuran keluarga atau permasalahan keluarga dapat menjadi pemicu terlibatnya anak dalam perdagangan, hal ini dikarenakan membuat anak tidak betah di rumah dan merasa tidak nyaman sehingga menyebabkan anak lari dari rumah.

Faktor eksternal penjualan anak: Pertama, Faktor Budaya. Trafficking tidak terlepas dari budaya setiap 
daerah yang ada yang terwujud dalam beberapa hal, peran perempuan dalam keluarga, kekuasaan, hierarki dan nilai-nilai sosial, serta peran anak dan tanggung jawabnya. Budaya merupakan faktor untuk seorang anak terlibat menjadi korban perdagangan anak, hal ini disebabkan karena nilai yang berkembang menyatakan bahwa seorang anak harus membayar semua kebaikan yang dilakukan orangtuanya. Hal ini yang membuat orangtua dan anak itu sendiri untuk terjebak menjadi korban. Budaya ini memiliki kekuatan yang nantinya akan berpengaruh juga pada terjadinya perdagangan orang.

Kedua, yaitu faktor Kurangnya Pendidikan dan Informasi. Rendahnya pendidikan dan buta huruf memberikan sumbangan pada terjadinya perdagangan. Kekurangtahuan akan informasi-informasi mengenai perdagangan anak membuat orang-orang lebih mudah untuk terjebak menjadi korban perdagangan anak khususnya di pedesaan dan terkadang tanpa disadari pelaku perdagangan anak tidak menyadari bahwa ia sudah melanggar hukum. Misalnya dalam penjualan anak melalui adopsi atau pengangkatan anak, akibat kekurangtahuan informasi tentang perdagangan anak dan prosedur pengangkatan anak sehingga timbul persepsi di masyarakat bahwa mengadopsi anak itu mudah, sehingga banyak masyarakat yang seringkali bertindak di luar hukum, maka dapat terjadi tindak pidana perdagangan anak.

Ketiga, Faktor akibat Peperangan. Peperangan dapat menjadi suatu faktor perdagangan anak, karena dimana peperangan melemahkan jiwa masyarakat sehingga terkadang membuat anak untuk lebih mudah diperdagangkan.

Keempat, Faktor akibat Bencana Alam. Bencana alam dapat juga menjadi faktor perdagangan anak, dikarenakan akibat bencana alam, banyak anak-anak yang terpisah dari orangtuanya karena orangtuanya telah meninggal sehingga harus tinggal sebatang kara. Hal inilah yang dimanfaatkan para pelaku perdagangan anak untuk memperdagangkan anakanak tersebut.

Kelima, Faktor Mudahnya Pembuatan KTP Palsu. Mudahnya pembuatan KTP palsu menjadi faktor perdagangan anak karena para pelaku perdagangan anak dengan ini akan mudah memperdagangkan anak-anak ke luar negeri secara ilegal.

Tindak pidana merupakan suatu perbuatan yang dilakukan oleh orang yang perbuatannya tersebut merupakan perbuatan yang dilarang oleh hukum pidana sehingga dapat dikenakan sanksi pidana. Orang yang melakukan tindak pidana tersebut dapat dimintai pertanggungjawaban pidana. Namun untuk dapat dimintai pertanggungjawaban pidana harus memenuhi unsur-unsur dari pertanggungjawaban pidana itu sendiri. Unsur yang pertama yaitu perbuatan yang dilakukan merupakan tindak pidana, kemudian unsur yang kedua yaitu kemampuan bertanggungjawab dengan artian bahwa orang tersebut dalam keadaan normal atau tidak cacat mental (waras), karena hanya dalam keadaan normal atau waras, seseorang dapat mengontrol perbuatan yang akan dilakukannya. Hal ini sesuai dengan pendapat Moeljatno bahwa, hanya terhadap orang-orang yang keadaan jiwanya normal sajalah, dapat kita harapkan akan mengatur tingkah lakunya sesuai dengan pola yang telah dianggap baik dalam masyarakat (Moeljatno, 2008:86). Kemudian unsur ketiga yaitu adanya kesalahan dalam tindak pidana tersebut, hal ini sesuai dengan asas dalam hukum pidana yaitu tidak dipidana jika tidak ada kesalahan atau geenstraf zonder schuld. Dalam unsur kesalahan terdapat 2 (dua) bentuk kesalahan yaitu kesengajaan (delik dolus) dan kealpaan (delik culpa).

Terkait dengan peristiwa penjualan anak yang terjadi di Jakarta Utara, tepatnya di Kampung Beting, Tugu Utara, Koja, seorang ibu yang menjual anaknya yang masih dalam kandungan dengan alasan bahwa untuk pelunasan utang-utangnya. Dalam peristiwa ini, perbuatan menjual anak yang dilakukan si ibu merupakan perbuatan yang dilarang dalam hukum pidana sehingga dapat dikenakan sanksi pidana, maka perbuatan si ibu tersebut merupakan tindak pidana. Atas tindak pidana yang dilakukan si ibu, maka si ibu dapat dimintai suatu pertanggungjawaban pidana karena si ibu telah memenuhi unsur-unsur dari pertanggungjawaban pidana itu yaitu dimana si ibu telah melakukan tindak pidana dan dalam melakukan perbuatannya itu si ibu dalam keadaan batinnya normal (waras) sehingga dikatakan mampu bertanggungjawab, dan ibu melakukan perbuatannya itu dengan sengaja menjual anaknya tanpa paksaan dari orang lain karena demi kepentingannya yaitu untuk pelunasan utang, sehingga dalam hal ini unsur kesalahan telah terpenuhi yaitu salah satu bentuk kesalahan adalah kesengajaan (delik dolus).

Dalam kasus penjualan anak ini, meskipun si ibu menjual anaknya dengan alasan akibat faktor kemiskinan, walaupun masih berupa penawaran, tetapi sudah ada 2 (dua) pembeli yang siap untuk membeli jika anak tersebut telah lahir dengan harga Rp.1.000.000,00 (satu juta rupiah), sehingga apapun alasannya si ibu dapat dikenakan sanksi pidana yang setimpal, karena tidak sepantasnya dia melakukan hal itu, apalagi dia sebagai ibu yang sedang mengandung 
anaknya, tetapi dia malah rela menjual darah dagingnya itu. Bilamana si ibu tidak mampu untuk membayar biaya persalinan, dia dapat mengajukan surat keluarga miskin ke pemerintah atau Komisi Perlindungan Anak Indonesia atau dengan cara lain yaitu mengadukan permasalahannya ke organisasi sosial atau Lembaga Swadaya Masyarakat setempat yang peduli akan perlindungan anak, sehingga pengaduan tersebut dapat diproses ke pemerintah setempat agar pengaduan ibu tersebut segera dapat diselesaikan demi kepentingan hak asasi anak. Hal ini sebagaimana telah diatur pada Pasal 44 ayat (1) dan Pasal 76 UU Perlindungan Anak.

Tertuang juga di dalam Pasal 44 ayat (1) UU Perlindungan Anak, pemerintah wajib menyediakan fasilitas dan menyelenggarakan upaya kesehatan yang komprehensif bagi anak, agar setiap anak memperoleh derajat kesehatan yang optimal sejak dalam kandungan. Serta tertuang dalam Pasal 76 UU Perlindungan Anak, Komisi Perlindungan Anak Indonesia bertugas: Melakukan sosialisasi seluruh ketentuan dan peraturan perundang-undangan yang berkaitan dengan perlindungan anak, mengumpulkan data dan informasi, menerima pengaduan masyarakat, melakukan penelaahan, pemantauan, evaluasi, dan pengawasan terhadap penyelenggaraan perlindungan anak; serta Memberikan laporan, saran, masukan, dan pertimbangan kepada Presiden dalam rangka perlindungan anak.

Kemudian bilamana ibu tersebut tidak mampu untuk bisa menjamin kesehatan atau kesejahteraan kehidupan anaknya kelak nanti, maka dia bisa menyerahkan anaknya kepada negara dan pemerintah. Karena negara dan pemerintah mempunyai kewajiban dan tanggung jawab untuk memberikan perlindungan terhadap anak bilamana orangtua dari anak tersebut tidak mampu untuk memberikan suatu perlindungan terhadap anaknya. Hal ini sebagaimana juga telah diatur pada ketentuan Pasal 45 ayat (1) dan (2) UU Perlindungan Anak. Adapun rumusan dari Pasal 45 ayat (1) dan (2) UU Perlindungan Anak sebagai berikut, Orangtua dan keluarga bertanggungjawab menjaga kesehatan anak dan merawat anak sejak dalam kandungan; Dalam hal orangtua dan keluarga yang tidak mampu melaksanakan tanggung jawab sebagaimana yang dimaksud dalam ayat (1), maka pemerintah wajib memenuhinya.

Peristiwa penjualan anak ini termasuk dalam tindak pidana perdagangan orang. Sehingga dalam penanganan kasus perdagangan orang menggunakan UU PTPPO, namun dalam peristiwa penjualan anak ini tidak dapat menggunakan pasal-pasal yang ada di
UU PTPPO, karena pasal-pasal yang ada pada UU PTPPO hanya mengatur bilamana terjadi penjualan anak dengan tujuan eksploitasi, di luar dari tujuan itu UU PTPPO tidak mengatur. Pada peristiwa penjualan anak yang terjadi ini, tujuan dari penjualan anak tersebut belum diketahui, sehingga bilamana menggunakan pasal-pasal yang ada dalam UU PTPPO, unsur-unsurnya tidak terpenuhi, sehingga untuk penanganan kasus ini menggunakan UU Perlindungan Anak. UU Perlindungan Anak selain mengatur mengenai hak-hak anak juga mengatur tentang ketentuan pidana untuk pelanggaran hakhak anak, salah satunya tentang penjualan anak. $\mathrm{Si}$ ibu dapat dijerat dengan menggunakan Pasal 83 UU Perlindungan Anak. Adapun rumusan dari Pasal 83 UU Perlindungan Anak yaitu setiap orang yang memperdagangkan, menjual, atau menculik anak untuk diri sendiri atau untuk dijual, dipidana dengan pidana penjara paling lama 15 (lima belas) tahun dan paling singkat 3 (tiga) tahun dan denda paling banyak Rp.300.000.000,00 (tiga ratus juta rupiah) dan paling sedikit Rp.60.000.000,00 (enam puluh juta rupiah).

Dengan melihat rumusan dari Pasal 83 UU Perlindungan Anak di atas, maka dapat disimpulkan unsur-unsurnya sebagai berikut, Pelakunya adalah setiap orang; Perbuatan yang dilakukan adalah memperdagangkan, menjual atau menculik; Subjek dari perbuatan tersebut adalah anak; Tujuan dari perbuatan yang dilakukan adalah untuk diri sendiri atau untuk dijual.

Unsur-unsur Pasal 83 UU Perlindungan Anak yang telah dijelaskan di atas dikaitkan dengan kasus seorang ibu yang menjual anak dalam kandungan yaitu sebagai berikut: Pelakunya adalah seorang ibu; Perbuatan yang dilakukan adalah menjual; Subjek dari perbuatan yang dilakukan anak yang masih dalam kandungan; Tujuan dari perbuatan tersebut adalah untuk diri sendiri, karena ibu tersebut menjual anaknya untuk membayar utang.

Penjelasan unsur-unsur Pasal 83 UU Perlindungan Anak yang telah dikaitkan dengan kasus seorang ibu yang menjual anak dalam kandungan di atas, bahwa unsur-unsur dari Pasal 83 UU Perlindungan Anak telah terpenuhi. Dengan terpenuhinya unsur-unsur dari Pasal 83 UU Perlindungan Anak dalam kasus seorang ibu yang menjual anak yang masih dalam kandungan, maka dalam penjatuhan pidananya dapat digunakan Pasal 83 UU Perlindungan Anak. Sehingga untuk mempertanggungjawabkan tindak pidana yang dilakukan ibu tersebut, dikenakan sanksi pidana penjara paling lama 15 (lima belas) tahun dan 
paling singkat 3 (tiga) tahun dan denda paling banyak Rp.300.000.000,00 (tiga ratus juta rupiah) dan paling sedikit Rp.60.000.000,00 (enam puluh juta rupiah) berdasarkan Pasal 83 UU Perlindungan Anak.

Pada peristiwa penjualan anak ini, bukan hanya si ibu yang bisa dijatuhi sanksi pidana atas perbuatannya tetapi suami sebagai kepala keluarga juga dapat dijatuhi pidana, karena suami dapat diduga menjadi pelaku penyuruh melakukan, dan/atau turut serta melakukan, penganjur, sesuai Pasal 55 ayat (1) angka ke-1 KUHP. Hal ini terjadi dengan alasan bahwa si ibu (istrinya) melakukan tindak pidana penjualan anak yang masih dalam kandungan, tidak mungkin tanpa sepengetahuan suami, apalagi dia menjual anak untuk pelunasan utang-utang, bahkan Ijazah dan Buku Pelaut suami dijaminankan.

\section{PENUTUP}

\section{Kesimpulan}

Berdasarkan dari penjelasan tersebut sebelumnya maka dapat disimpulkan bahwa, seorang ibu yang menjual anak masih dalam kandungan, serta telah lalai dan telah melanggar tanggungjawab dan kewajiban sebagai orangtua atas perbuatannya. Maka dikenakan Pasal 83 UU Perlindungan Anak yaitu dijatuhi pidana dengan sanksi pidana penjara paling lama 15 (lima belas) tahun dan paling singkat 3 (tiga) tahun dan denda paling banyak Rp.300.000.000,00 (tiga ratus juta rupiah) dan paling sedikit Rp.60.000.000,00 (enam puluh juta rupiah).

\section{Rekomendasi}

Berdasarkan atas kesimpulan tersebut di atas maka disarankan kepada penegak hukum untuk tidak segan-segan memberikan sanksi yang terberat sesuai dengan peraturan yang berlaku, dan untuk ibu yang menjual anak masih dalam kandungan, ini menjadikan tugas pemerintah untuk memberi pemahaman dengan dibekali nilai-nilai moral, etika, dan terlebih dalam kehidupan bermasyarakat dan berbangsa.

\section{DAFTAR PUSTAKA}

\section{Buku:}

Farhana, 2010, Aspek Hukum Perdagangan Orang di Indonesia, Cetakan pertama, Jakarta: Sinar Grafika.

Moeljatno, 2008, Asas-asas Hukum Pidana, Cetakan Kedelapan, Jakarta: Rineka Cipta.

Saraswati, Rika, 2009, Hukum Perlindungan Anak di Indonesia, Cetakan Pertama, Bandung: Citra Aditya Bakti.

\section{Peraturan Perundang-undangan:}

Kitab Undang-Undang Hukum Pidana.

Undang-Undang Republik Indonesia Nomor 39 Tahun 1999 tentang Hak Asasi Manusia.

Undang-Undang Republik Indonesia Nomor 23 Tahun 2002 tentang Perlindungan Anak.

Undang-Undang Republik Indonesia Nomor 21 Tahun 2007 tentang Pemberantasan Tindak Pidana Perdagangan Orang.

\section{Website:}

http://komnaspa.wordpress.com/2011/12/21/catatanakhir-tahun-2011-komisi-nasional-perlindungananak/.

http://megapolitan.kompas.com/read/2010/02/12/ 08391384/bayi.dalam.Kandungan.pun.Dijual.R p.1,Juta.

http://uripsantoso.wordpress.com/2009/04/26/ kewajiban-orang-tua-terhadap-anak/. 